\title{
Patients satisfaction to quality of health services of family doctors in family medicine centers in left side of Mosul city
}

\author{
Mohammad Yousif Mohammad*, Firas Husam Ali**, Ammar Hazim Yahia*** \\ *NinevehHealth Directorate /Public health department/ Immunization division / Manager of immunization \\ unit , ${ }^{* \star}$ Nineveh Health Directorate/Manager atAl - Quds Family medicine training center , ${ }^{* \star *}$ Nineveh Health \\ Directorate/ Assistant Manager at Al - Quds Family medicine training center. \\ Correspondence: mohamadalibrahimy@gmail.com
}

(Ann Coll Med Mosul 2020; 42 (1):76-81).

Received: 31 ${ }^{\text {st }}$ Dec. 2019; Accepted: $30^{\text {th }}$ May 2020.

\section{ABSTRACT}

Background: Patient satisfaction is related to clinical outcomes, patient retention, and medical malpractice claims. It affects the timely, efficient, and patient-centered delivery of quality health care. The aim of study was to assess the level of patients' satisfaction.to doctors in family medicine centers in Mosul city.

Patients and Methods: A cross sectional study was conducted in order to achieve the aim of the present study in which the data was taken from the attendantsto family medicine centers in left side of Mosul city by direct interview using specially designed questionnaire (The Bulgarian EUROPEP questionnaire) after receiving health services during a period of 8 months started from $1^{\text {st }}$ of May 2018 up to $30^{\text {th }}$ of January 2019.

Results: The study includes 580 participants. More than half of them their ages were between $20-40$ years from both sexes (male $=175$, female $=135$ ) and $38.8 \%$ of them were having university graduation. The overall satisfaction to medical services delivered by family doctors was $79.7 \%$, Continuity and confidentiality constituted the higher satisfaction rate in $97 \%, 96.6 \%$, while Informativeness satisfaction constitute $89.7 \%$. Accessibility and Acceptability had the lowest satisfaction rate compared to other domains.

Conclusions: this study revealed high patients'satisfaction rateto doctors delivering health care at the family health centers in left side of Mosul city while there was lower satisfaction rate regarding Accessibility and Acceptability. Further wide scale studies are needed in the futureand provision of appropriate infrastructure.

Keywords: patient satisfaction, family medicine, health care.

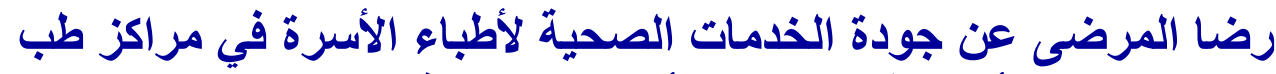

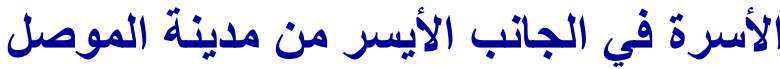

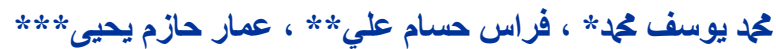

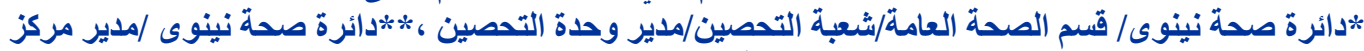

$$
\begin{aligned}
& \text { القدس لطب الاسرة ،**ثـدائرة صحة نينوى /وكيل مدير مركز القدس لطب الاسرة. }
\end{aligned}
$$

الخلفية: يرتبط رضا المرضى بالنتائج السريرية واحتباس المرضى ومطالبات سوء الممارسة الطبية. ويؤثر على تقديم رعاية

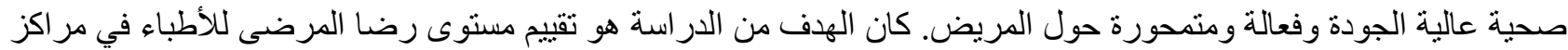
طب الأسرة في مدينة الموصل. المرضى والطرق: تم إجر اء دراسة مقطعية من أجل تحقيق هدف الدراسة الحالية حيث تم أخذ البيانات من المر اجعين إلى مر اكز

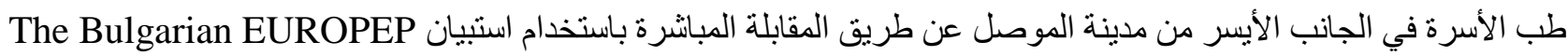

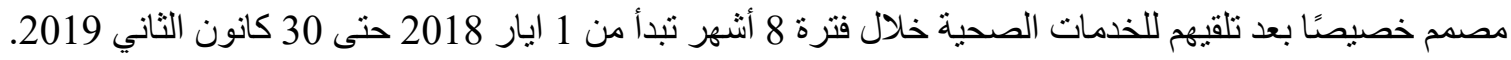


النتائج: تضمنت الدراسة 580 مشارك. كان أكثر من نصفهم تتراوح أعمار هم بين 20-40 سنة من الجنسين (الذكور = 175 ، 138 ،

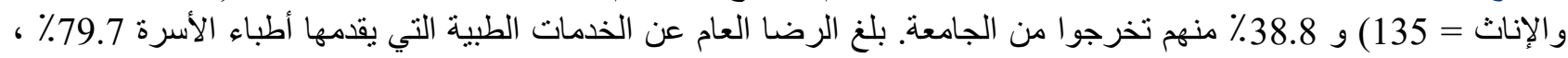

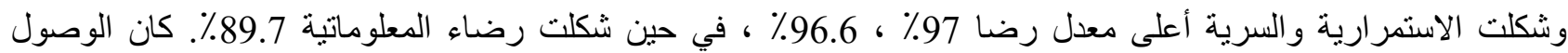

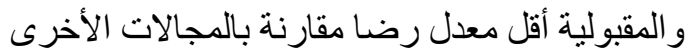

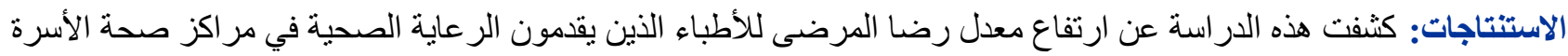

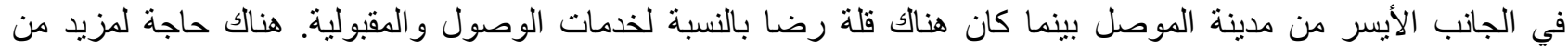
الدراسات و اسعة النطاق في المستقبل وتوفير البنى التحتية الملائمة.

الكلمات المفتاحية: إرضاء المريض، طب الأسرة، الرعاية الصحية.

\section{INTRODUCTION}

atient satisfaction is "an indicator for measuring the quality in health care".

Patient satisfaction is an important and commonly used indicator for measuring the quality and efficiency in health care system. ${ }^{2}$.The potential cost-effectiveness of qualitative techniques involved in designing patient satisfaction surveys became significantly important. ${ }^{3}$ Patient satisfaction is related totheir clinical outcomes, and decrease medical malpractice claims. It leads to patient-centered delivery of quality health care. Patient satisfaction is thus considered a very effective indicator to measure the success of doctors and hospitals. ${ }^{4}$ Literatures showed that satisfied patients are more likely to develop a good relationship with the health system, leading to improve compliance, continuity of care and ultimately better health outcome. ${ }^{5}$ The Internet encourages rapid and wide distribution of these opinions ${ }^{6}$.

The cost of obtaining a patient is high, so that, losing patient is a big loss in medical investment. ? "There is evidence of a mutual relationship between patient satisfaction and continuity of care (which is associated with better patient outcomes). On the other hand, dissatisfaction and complaints can mean not only loss of business/investment, but also increased risk of malpractice lawsuits." 8 "health quality improvement, and risk management is greatly linked with continuity of patient care, which is important for surveying patient satisfaction through which can offer the patients a chance to participate in their care by reporting their care experiences and building engagement."

Aim of study: The aim of study was to assess the level of patients' satisfaction to doctors in family medicine centers in Mosul city.

\section{Subjects and Methods}

The protocol was approved by Ethical and Scientific Committee in Nineveh health sector,and obtaining consent from each participant througha signedagreement letter. If the participants were children, their relatives were involved in the interview. This study was conducted in a sample of family medicine centers in the left bank of Mosul citywhich were selected by simple random sampling technique out of six centers, namely (AlQuds, Al-Araby and Al-Qadesya family medicine centers).A cross sectional study was conducted in order to achieve the aim of the present study in which the data were taken from the attendants to each centers through direct interview using specially designed questionnaire (The Bulgarian EUROPEP questionnaire) ${ }^{10}$ after receiving health services. In order to achieve the purpose of the study,an adequate sample size is calculated to estimate thepopulation included in the study with a good precision. The total number of attendance to the three family centers over a period of one month were calculated and according to the equation of sample calculation for cross sectional study with standard error $5 \%$ and $95 \%$ confidence level ${ }^{11}$ the sample was estimated, however; in order to overcome bias, higher number of participants were included in the study, that is out of the 6580 total attendants to the three family centers over a period of one month, five hundred and eightyattendants were randomly selected from each center every 2 other days in successive manner, as a week divided in to six days every 3 days return to the same center for collection of data over a period of eight month from $1^{\text {st }}$ of May 2018 up to $30^{\text {th }}$ of January 2019. In each center, the rule of inclusion patients was depending on numbers of family physician providing services in each center. If there was one doctor in the center, so every other patient was included in the study for purpose of randomization, while in center, where there was more than one doctor providing services, attendants were included in the study from each doctorin a manner of one by one from each doctors. No exclusion criteria were applied apart from randomization process. The sample size taken was higher than the required for

The Europep instrument is a questionnaire that included 21 items that categorized into 7qualitative 
domains each measuring different aspects of care including (Confidentiality, Thoroughness $\{a$ large amount of care and attention to detail\} , Informativeness \{ giving information; instructive in clarity\}, Continuity\{is concerned with quality of care over time\}, Accessibility\{the availability of good health services within reasonable reach of those who need\}, Humaneness \{the importance of human needs and values \} andAcceptability\{the extent to which people receiving a healthcare intervention consider it to be appropriate stop human suffering\}), all items are aggregated into 2 dimensions: clinical behavior (items $1-16$ ) andorganization of care (items $17-21$ ). Data analysis were done using SPSS software with calculation of $Z$ test of one proportion to find out significance in specific domain.

\section{RESULTS}

This study revealed that $310(53.5 \%)$ of the attendantstheir ages between $20-40$ years withmale: to femaleratio 1.1:1, table 1.

Table (1): Distribution of study population according to age and gender

\begin{tabular}{|l|l|l|l|l|l|l|l|}
\hline \multirow{2}{*}{ Age group (inyears) } & \multicolumn{3}{|l|}{ Male } & Female & \multicolumn{2}{l|}{ Total } & $\mathrm{P}^{*}$ \\
\cline { 2 - 8 } & value \\
\hline$<20$ & 35 & 6 & No. & $\%$ & No. & $\%$ & \\
\hline $20-40$ & 175 & 30.2 & 135 & 23.3 & 310 & 53.5 & 0.045 \\
\hline$>40$ & 95 & 16.4 & 95 & 16.4 & 190 & 32.8 & 0.38 \\
\hline Total & 305 & 52.6 & 275 & 47.4 & 580 & 100 & \\
\hline
\end{tabular}

${ }^{*} \mathrm{P}$ value calculated used Chi square test with degree of freedom $=1$

Table 2 demonstrate that educational level of the study population, were $225(38.8 \%)$ graduated from the university with only $8.6 \%$ of the attendee were illiterate, with significant difference between male and female in most of the educational level.

Table (2): Educational level of the study population according to sex

\begin{tabular}{|l|l|l|l|l|l|l|l|}
\hline \multirow{2}{*}{ Education level } & Male & \multicolumn{7}{l}{ Female } & Total & \multirow{2}{*}{ P value } \\
\cline { 2 - 8 } & No. & $\%$ & No. & $\%$ & No. & $\%$ & \\
\hline Illiterate & 15 & 2.6 & 35 & 6.0 & 50 & 8.6 & 0.0008 \\
\hline Read \& write & 45 & 7.8 & 30 & 5.2 & 75 & 12.9 & 0.16 \\
\hline Primary school & 35 & 6.0 & 15 & 2.6 & 50 & 8.6 & 0.009 \\
\hline Secondary school & 80 & 13.8 & 100 & 17.2 & 180 & 31.0 & 0.008 \\
\hline University & 130 & 22.4 & 95 & 16.4 & 225 & 38.8 & 0.046 \\
\hline Total & 305 & 52.6 & 275 & 47.4 & 580 & 100 & \\
\hline
\end{tabular}

${ }^{*} \mathrm{P}$ value calculated used $\mathrm{Chi}$ square test with degree of freedom $=1$

Table 3 elucidate that $200(34.5 \%)$ of study sample were employee (male $=120$, female $=80$ ) and 135 $(23.3 \%)$ of the sample was house wife, the difference between employment status and working as students was statistically significant between male and femalwith $p$ value $=0.018,0.009$, respectively.

Table (3): distribution of study population according tooccupation and gender

\begin{tabular}{|c|c|c|c|c|c|c|c|}
\hline Occupation & \multicolumn{2}{|c|}{ Male } & \multicolumn{2}{|c|}{ Female } & \multicolumn{2}{|c|}{ Total } & \multirow[t]{2}{*}{$\mathrm{P}$ value ** } \\
\hline & No. & $\%$ & No. & $\%$ & No. & $\%$ & \\
\hline Housewife & 0 & 0.0 & 135 & 23.3 & 135 & 23.3 & - -----*** $^{*}$ \\
\hline Employee & 120 & 20.7 & 80 & 13.8 & 200 & 34.5 & 0.018 \\
\hline Student & 50 & 8.6 & 60 & 10.3 & 110 & 18.9 & 0.009 \\
\hline Skill worker & 115 & 19.8 & 0 & 0.0 & 115 & 19.8 & $----^{* * *}$ \\
\hline Retired & 5 & 0.9 & 0 & 0.0 & 5 & 0.9 & $----^{\star \star \star *}$ \\
\hline Others ${ }^{*}$ & 15 & 2.6 & 0 & 0.0 & 15 & 2.6 & $----^{\star \star \star *}$ \\
\hline Total & 305 & 52.6 & 275 & 47.4 & 580 & 100 & \\
\hline
\end{tabular}

${ }^{*}$ Others were those who cannot include them in the above classification, like unskilled workers and others.

${ }^{* *} P$ value calculated used Chi square test with degree of freedom $=1$

***unable to calculate as chi sqaure does not support cell values that are zero. 
Lastly table 4 demonstrates satisfaction rates to medical services delivered through these family centers which represent that the overall satisfactions was $79.7 \%$ of the sample, and Confidentiality constitute $95 \%$ of the study population.Thoroughness and Continuity satisfaction rate were $97.4 \%$ and $93.1 \%$ respectively. Informativeness constitute $89.7 \%$. Accessibility and Acceptability showed the lowest satisfaction rate $50 \%$, $47.7 \%$ respectively. Using $Z$ test of one proportion analysis shows significant difference between each domain related to others with $P$ value less than 0.001 which is very highly significant.

Table (4): Satisfaction rates to the medical services delivered by the family centers

\begin{tabular}{|c|c|c|c|c|c|}
\hline \multirow{2}{*}{ Overall satisfaction } & \multicolumn{2}{|l|}{ Yes } & \multicolumn{2}{|l|}{ No } & \multirow{2}{*}{$P$ value* } \\
\hline & No. & $\%$ & No. & $\%$ & \\
\hline & 462 & 79.7 & 118 & 20.3 & 0.000 \\
\hline \multirow{2}{*}{ Domain } & \multicolumn{2}{|c|}{ Satisfied } & \multicolumn{2}{|c|}{ Unsatisfied } & \\
\hline & No. & $\%$ & No. & $\%$ & \\
\hline Confidentiality & 555 & 95.7 & 25 & 4.3 & 0.000 \\
\hline Thoroughness & 540 & 93.1 & 40 & 6.9 & 0.000 \\
\hline Informativeness & 520 & 89.7 & 60 & 10.3 & 0.000 \\
\hline Continuity & 565 & 97.4 & 15 & 2.6 & 0.000 \\
\hline Accessibility & 290 & 50 & 290 & 50 & 0.000 \\
\hline Humaneness & 500 & 86.2 & 80 & 13.8 & 0.000 \\
\hline Acceptability & 275 & 47.4 & 305 & 52.6 & 0.000 \\
\hline
\end{tabular}

${ }^{\star} Z$ test of one proportion was used to find out the significance of difference between different domains.

\section{DISCUSSION}

The degree of patient satisfaction can be used as ways of assessing the quality of health care and the personnel. "It reflects the ability of the provider to meet patients' needs. Satisfied patients are more likely than unsatisfied patients to continue using health care services, maintain their relation-ships with specific health care providers, and comply with care regimens" ${ }^{12}$. Thus, it can be defined as the corner stone for national health. It has been reported that the cost-efficiency of health care would be better by transitioning the focus towards primary health care ${ }^{13}$ Studies have proved that" a satisfied client is more likely to comply with medical treatment, more likely to provide medically relevant information to the provider, and more likely to continue using the health" 14 .

Thepresent studyshows thathalfof attendants to family medicine centers in left side Mosul city their age was between 20 - 40 years $(30.2 \%$ male and $23.3 \%$ female) and $38.8 \%$ of the study sample were graduates from the university. Similar age distribution was obtained from other study conducted in Saudi Arabia which have been done on participants attending to their family centers, but $73.5 \%$ of attendee were male ${ }^{15}$, this male predominance may be due to the religious point of view as more man go out than female. This age distribution was found also in Nigeria were $68.1 \%$ of the sample of attendee their ages between (20 39 years) on the other hand the majority of them were females who constitute $(71.3 \%)$ of the attendance to the family health centers ${ }^{16}$ and this exhibition of a younger age may be related to the high fertility and the culture prevalent in this region. About thirty eight percent of present study population has completed their university education similarly to data obtained from Jubail city in Saudi Arabia ${ }^{17}$ but unlike other similar study implemented in Al Khartoum state which found that only $10.1 \%$ of the study sample was graduates from the university ${ }^{18}$.

The present study demonstrates that $79.7 \%$ of the participants were expressing their overall satisfaction regarding health services delivered by family doctors in family medicine centers in left side of Mosul city.

These findings are relatively similar to other studies achieved in Riyadh, Saudi Arabia and Jahrom of Shiraz, Iran which found that the overall satisfaction to health services provided by $\mathrm{PHC}$ centers was $64.5 \%{ }^{19}$ and $(66.7 \%)^{20}$, respectively. The doctors who gave an opportunity to patients to talk about their illness, provided instructions regarding dose and time of medication. advised follow up to the patients were constitute $93.1 \%$, $89.7 \%$ respectively as represented by thoroughness and Informativeness. Contrary results were obtained from a study done in Scotland ${ }^{21}$ as only half of patients were reasonably satisfied with 14 various aspects of doctor-patient interaction and $(87 \%),(79 \%)$ were the satisfaction rate regarding doctors' thoroughness and Informativeness; respectively. This difference in 
satisfaction rate may be related to the level of population knowledge about the importance of malpractice claim andits effectsrelated to upgrading of health system. In the present study Humaneness satisfaction rate constitute about $86 \%$ of study population Same result obtained from other international studies which reported that about88-92\% of their patients believed that they were treated with respect and dignity 22-24. Acceptability satisfaction rate was relatively low in the present study which constitute just $47.4 \%$. This domain regarded out of doctors controls as there is limited resources available at the family centers to be supplied to the patients which is due to the destruction of the infrastructures that happened to the Mosul city during ISIS war.

\section{CONCLUSION}

Patients were highly satisfied with doctors giving health services at the family health centers in left side of Mosul city.

\section{RECOMMENDATIONS}

It is recommended that further studies should beconducted to assess patient satisfaction to family medicine doctors including larger sample size and including the family physician doctors in different parts of Mosul city even in the private clinic.

Conflict of Interest

No conflict of interest.

Role of Funding Source

Authors self-supported study.

\section{REFERENCES}

1.Prakash B. Patient SatisfactionJCutanAesthet Surg. 2010 Sep-Dec; 3(3): 151-155. doi: 10.4103/0974-2077.74491

2.Merkouris A, Andreadou A, Athini $E$, Hatzimbalasi M, Rovithis M, Papastavrou E.Assessment of patient satisfaction in public hospitals in Cyprus: a descriptive study . health Science Journal v1, 2013, Vol. 7, pp. 28-40.

3.Carr-Hill.RA, The measurement of patient satisfaction. Journal of Public Health, 1922, Vol. 14, 3, pp. 236-249.

4.Mohamed EY, Sami W,Alotaibi A ,AlfaragA,Almutairi A and Alanzi F.Patients' Satisfaction with Primary Health Care Centers' Services, Majmaah, Kingdom of Saudi of Saudi Arabia. 2, Int J Health Sci, 2015,Vol. 9, pp. 163170.
5. Fitzpatrick, R.Surveys of patient satisfaction: II: Designing a questionnaire and conducting a survey. 1991, BMJ., Vol. ;302:, pp. 1129-32.

6. Segal, J.The role of the Internet in doctor performance rating. Pain Physician., 2009,Vol. 12, pp. 659-664.

7. Saultz JW, Lochner J.Interpersonal continuity of care and care outcomes: a critical review. Ann Fam Med., 2005,Vol. 3, pp. 159-166.

8. Clarke, RN.Measuring patient loss. J Med Pract Manage, 2002, Vol. 17, pp. 183-186.

9.Van Servellen G, Fongwa M, MockusD'ErricoE.Continuity of care and quality care outcomes for people experiencing chronic conditions: $A$ literature review.Nurs Health Sci.,2006, Vol. 8, pp. 185-195.

10. Dimova R, Stoyanova R, Keskinova D. The EUROPEP questionnaire for patient's evaluation of general practice care: Bulgarian experience. .2017, Croat Med J., Vol. 58(1):, pp. 63-74.

11. Charan J, Biswas T. How to calculate sample size for different study designs in medical research?., Indian J Psychol Med. ;2013 , Vol. 35(2), pp. :121-126.

12.Asadi-Lari M, TamburiniM , and Gray D.Patients' needs, satisfaction, and health related quality of life: Towards a comprehensive model. 2004; , Health Qual Life Outcomes. , Vol. 2:, p. 32.

13.Shi..L. The Impact of Primary Care: A Focused Review., ,Scientifica (Cairo). 2012; p. 432892. .

14.Cleary PD, Edgman-Levitan S, Roberts $M$, MoloneyTW, McMullen W, Walker JD, et al. Patients evaluate their hospital care: a national survey. 1991; , Health Affairs, Vol. 10: , p. 25467.

15. Gouveia GC, Souza WV , Luna CF , SouzaJunior PR, Szwarcwald CL., [ed.]. Health care users' satisfaction in Brazil., Cad SaudePublica, 2005; Vol. 21:, pp. 109-18.

16.Jawaid M, Ahmed N, Alam SN, Rizvi BH, Razzak HA. Patients experiences and satisfaction from surgical outpatient department of a tertiary care teaching hospital. ., Pak J Med Sci , 2009, Vol. ;25(3):, pp. 439-42.

17.Alia Almoajel, EbtisamFetohi and Amani Alshamrani.Patient Satisfaction with primary Health Care in Jubail City, Saudi Arabia .2014:, 
World Journal of Medical Sciences, Vol. 11 (2): , pp. ; 255-264.

18. Wagialla N A, Elnimeiri M, Hassan M, Alawad AO, Ahmed A, AbdulrahmanA.Patients' Satisfaction with the Quality of Provided Services for Management of Hypertension in Public Primary Health Care Facilities, Sharg-Alneel Locality, Khartoum State, Sudan., Public Health Open J., 2018; Vol. 3(1), pp. : 13-19.

19. Al-Sakkak MA1, Al-Nowaiser NA, Al-Khashan HI, Al-Abdrabulnabi AA, Jaber RM.Patient satisfaction with primary health care services in Riyadh. .Mar;, Saudi Med J. , 2008, Vol. 29(3):, pp. 432-6.

20. ZamZare A, Taheri L and Jahromi M K. Clients Satisfaction with Primary Health Care in Jahrom: A Cross-Sectional Study on Iranian Health Centers. Int. J. Curr. Microbiol, 2015. App.Sci, Vol. 4(3):, pp. 84-89.

21. Otani $\mathrm{K}$, Herrmann $\mathrm{p}$ and KurzR .Improving patient satisfaction in hospital care settings. ;, Health Services Management Research, 2011,, Vol. 24(4):, pp. 163-9 .

22.Merkouris A, Andreadou A, Athini E, Hatzimbalasi M, Rovithis M, Papastavrou E.Assessment of patient satisfaction in public hospitals in Cyprus: a descriptive study ., , health Science Journal v, 2013, Vols. Vol. 7(1,), pp. pp. 28-40.

23. Rodriguez HP, von Glahn $\mathrm{T}$, Chang $\mathrm{H}$, Rogers WH, Safran DG. Measuring patients' experience with individual specialist physicians and their practices.., Am J Med Qual., 2009,Vol. Vol. 9, pp. pp. 35-44.

24. Alzaied A., and Alshammari TA. An Evaluation of Primary Healthcare Centers (PHC) Services: The Views of Users. February 20, , Health Science Journal , 2016. 